\title{
Efektivitas Model Project Based Learning Pada Mata Kuliah Vulkanologi Terhadap Hasil Belajar Mahasiswa
}

\author{
Jeilen G. N. Nusa \\ Program Studi Fisika, Fakultas MIPA, Universitas Negeri Manado \\ Email: jeilennusa@unima.ac.id
}

\begin{abstract}
This study aims to determine the effectiveness of learning using the Project-Based Learning (PjBL) Model or project-based learning on student learning outcomes in volcanology courses. This study used a quasiexperimental design with a Nonequivalent (Pretest-Posttest) Control Group Design. The study population was all students who contracted the Volcanology course in the Physics Study Program of the Faculty of Mathematics and Natural Sciences UNIMA for the 2019-2020 Odd Academic Year. The sample used the purposive sampling technique and divided the experimental class and the control class. The research data were collected using a test instrument for the comprehension ability of the material. The results showed that the average student learning outcomes in the experimental class were $89.74 \%$, higher than the control class $72.11 \%$. The results of statistical test analysis, namely $t$-test, obtained the value of t count 3.80 greater than t table, namely 2.10 with a real level $\alpha=0.05$, which means that the effectiveness of project-based learning models (Project Based Learning) on learning outcomes students are better than conventional learning models.
\end{abstract}

Keywords: Effectiveness, Project Based Learning, Learning Outcomes

Abstrak. Penelitian ini bertujuan untuk mengetahui efektifitas pembelajaran menggunakan Model Project Based Learning (PjBL) atau pembelajaran berbasis proyek terhadap hasil belajar mahasiswa dalam perkuliahan mata kuliah vulkanologi. Penelitian ini menggunakan desain quasi experiment dengan rancangan Nonequivalent (PretestPosttest) Control Group Design. Populasi penelitian adalah seluruh mahasiswa yang mengontrak mata kuliah Vulkanologi pada Program Studi Ilmu Fisika FMIPA UNIMA Tahun Akademik Ganjil 2019-2020. Sampel menggunakan teknik purposive sampling dan membagi kelas eksperimen dan kelas kontrol. Data penelitian dikumpulkan dengan mengunakan instrumen tes kemampuan pemahaman materi. Hasil penelitian menunjukan ratarata hasil belajar mahasiswa pada kelas eksperimen sebesar 89,74\%, lebih tinggi dibanding kelas kontrol 72.11\%. Hasil analisis uji statistik yaitu t-Test, diperoleh nilai t hitung 3,80 lebih besar dari t tabel yaitu 2,10 dengan taraf nyata $\alpha=$ 0,05, yang artinya bahwa efektivitas model pembelajaran berbasis proyek (Project Based Learning) terhadap hasil belajar mahasiswa lebih baik dibanding model pembelajaran konvensional.

Kata Kunci: Efektivitas, Project Based Learning, Hasil Belajar

\section{PENDAHULUAN}

Tak terlepas di pendidikan tinggi, dampak era revolusi industri 4.0 mengharuskan sebuah perubahan baik dalam pengajaran maupun pembelajaran. Hal tersebut ditujukan, agar supaya menghasilkan para lulusan yang sudah siap untuk terjun ke masyarakat dengan memiliki kemampuan (skill) individu yang mumpuni dan berdaya saing tinggi. Pendidikan dan pengajaran dalam proses perkuliahan di Program Studi Fisika Fakultas Matematika dan IPA Universitas Negeri Manado, dituntut untuk melakukan sebuah terobosan dalam meningkatkan kualitas mutu pendidikan. Terlebih pada mata kuliah Vulkanologi, yang bukan sekedar mempelajari tentang gunung api, faktor-faktor pembentukan ataupun parameter fisika dan sistem panas bumi, tetapi juga berkaitan dengan eksplorasi sumber daya alam sampai pada pengelolaan kebencanaan. Hal ini tidak terlepas dari keberadaan indonesia yang secara geologis, berada di antara tiga lempeng tektonik besar yaitu eurasia, indo-australia, dan pasifik. Pergerakan lempeng-lempeng tersebut dapat membuat magma naik dan membentuk kerucut-kerucut gunung berapi. Di samping itu, letak kampus Universitas Negeri Manado maupun sosial kehidupan masyarakat di Minahasa yang rentan, berada dalam rangkaian jalur pegunungan berapi yang masih aktif seperti gunung Lokon, gunung 
Soputan, gunung Mahawu dan juga masih ada sumber-sumber panas bumi lainnya.

Untuk itu pemahaman pengetahuan bagi mahasiswa juga tidak cukup apabila tidak mengamati aktivitas dari sumbersumber vulkanologi tersebut dengan cara mereka turun langsung ke lapangan. Karena vulkanologi merupakan suatu bagian dari ilmu fisika yang mempelajari tentang gunung berapi, lava, magma, dan fenomena geologi.

Londa, dkk (2019) menjelaskan bahwa proses pembelajaran konvensional yaitu ceramah, diskusi dan lain sebagainya dinilai sangat tidak tepat digunakan dalam proses perkuliahan yang sebenarnya mengharuskan kemampuan tingkat tinggi mahasiswa, ini disebabkan karena metode tersebut hanya mempertegas teorinya saja dan bahkan banyak mahasiswa pada saat proses perkuliahan hanya diam tidak aktif bahkan ada yang hanya sibuk dengan mengutak-atik smartphone yang dimilikinya karena merasa bosan dan ngantuk dalam kelas dan hanya sebagian kecil dari mahasiswa yang memperhatikan kegiatan pembelajaran tersebut.

Proses belajar dan mengajar pada perkembangan ilmu pengetahuan dan teknologi semakin mendorong upaya-upaya pembaharuan dalam pemanfaatan teknologi dalam pembelajaran (Mambu, dkk, 2018). Sejatinya pembelajaran merupakan proses yang membantu siswa untuk memperoleh informasi, ide, keterampilan, nilai, cara berpikir, dan cara-cara belajar bagaimana belajar. pembelajaran harus benar-benar memperhatikan keterlibatan siswa, khususnya keaktifan siswa selama mengikuti kegiatan pembelajaran tersebut.

Problematika pembelajaran dalam proses perkuliahan masih ditemukan capaian yang belum optimal atau skala memuaskan. Ditemukan keaktifan dan kemampuan berpikir kreatif mahasiswa masih tergolong rendah. Penyebabnya antara lain aktivitas belajar yang sepenuhnya dilakukan dalam kelas saja ataupun tindak lanjut yang hanya untuk memenuhi penyelesaian kegiatan perkuliahan. Oleh karena itu, diperlukan suatu pola atau model pembelajaran yang dapat meningkatkan keaktifan dan kemampuan berpikir kreatif mahasiswa. Salah satu model pembelajaran yang dapat diterapkan adalah Project Based Learning atau dikenal sebagai Pembelajaran Berbasis Proyek (PjBL).

Pembelajaran berbasis proyek merupakan pembelajaran yang berpusat pada proses, relatif berjangka waktu, berfokus pada masalah, unit pembelajaran bermakna dengan memadukan konsep-konsep dari sejumlah komponen baik itu pengetahuan, disiplin ilmu atau lapangan (Ngalimun, 2013). Pembelajaran ini menekankan pada pengajaran yang berpusat pada siswa dengan penugasan proyek. Pembelajaran berbasis proyek memberikan kesempatan kepada siswa untuk bekerja lebih otonom, untuk mengembangkan pembelajaran sendiri, lebih realistik dan menghasilkan suatu produk. (Ida Ayu Kade, Sadia, \& Muderawan, 2013)

Pembelajaran berbasis proyek dipilih karena pada kegiatan pembelajarannya berlangsung secara kolaboratif dalam kelompok yang heterogen. Pembelajaran berbasis proyek memiliki potensi yang sangat besar untuk melatih keaktifan serta proses berpikir pada mahasiswa yang mengarah pada keterampilan berpikir kreatif. Pada dasarnya, keterampilan berpikir kreatif dikembangkan di setiap tahapan pembelajaran model pembelajaran berbasis proyek, sedangkan mahasiswa menjadi terdorong di dalam belajar mereka, dan guru/ dosen berperan sebagai mediator atau fasilitator.

Tujuan penelitian ini adalah untuk mengetahui Efektivitas model pembelajaran berbasis proyek (Project Based Learning) pada mata kuliah Vulkanologi terhadap hasil belajar mahasiswa.

\section{METODE}

Penelitian ini menggunakan desain quasi experiment dengan rancangan Non equivalent (Pretest-Posttest) Control Group Design. Populasi penelitian adalah seluruh mahasiswa yang mengontrak mata kuliah Vulkanologi Program Studi Ilmu Fisika FMIPA UNIMA Tahun Akademik Ganjil 
2019-2020. Penentuan sampel menggunakan teknik purposive sampling dan membagi kelas eksperimen dan kelas kontrol. Kemudian diberi pretest sebelum perlakuan untuk mengetahui apakah ada perbedaan antara kelompok eksperimen dan kelompok kontrol. Menurut Sugiono (2008), perbedaan antara pretest dan posttest diasumsikan merupakan efek dari perlakuan atau eksperimen.

$$
\begin{array}{|lll|}
\hline \mathrm{O}_{1} & \mathrm{X} & \mathrm{O}_{2} \\
\mathrm{O}_{3} & & \mathrm{O}_{4} \\
\hline
\end{array}
$$

Gambar 1. Quasi Experimental Design dengan Nonequivalent Pretest-Posttest Control Group Design

Keterangan :

O1 dan O3 : Hasil pretest sebelum diberi perlakuan/ treatment

X : Pelaksanaan model pembelajaran berbasis proyek pada kelas eksperimen.

$\mathrm{O} 2$

: Hasil belajar siswa yang diberi perlakuan pembelajaran berbasis proyek.

$\mathrm{O} 4$

: Hasil belajar siswa yang tidak diberi perlakuan pembelajaran berbasis proyek.

\section{HASIL DAN PEMBAHASAN}

Untuk mengetahui efektivitas pembelajaran yang diterapkan dengan dua model terhadap hasil belajar diberikan beberapa item pertanyaan menyangkut pemahaman kepada 20 mahasiswa dalam masing-masing kelas. Hasil respon mahasiswa terhadap model pembelajaran, diolah dan dianalisis menggunakan metode statistik parametrik.

Hasil analisis menunjukkan bahwa terdapat perbedaan hasil belajar mahasiswa terhadap model pembelajaran yang diterapkan. Diperoleh nilai rata-rata kelas, sebesar $89,74 \%$ (eksperimen) dan $72,11 \%$ (kontrol) yang artinya model pembelajaran berbasis proyek sangat baik untuk diterapkan.

Tabel 1. Deskripsi Statistik Hasil Belajar Mahasiswa

\begin{tabular}{lrr}
\hline & Eksperimen & \multicolumn{1}{c}{ Kontrol } \\
\hline Mean & 89.74 & 72.11 \\
Standard Error & 2.55 & 2.74
\end{tabular}

\begin{tabular}{lrr} 
Median & 95.00 & 70.00 \\
Mode & 100.00 & 60.00 \\
Standard Deviation & 11.11 & 11.94 \\
Sample Variance & 123.54 & 142.54 \\
Kurtosis & -0.06 & -1.20 \\
Skewness & -1.01 & 0.45 \\
Range & 35.00 & 35.00 \\
Minimum & 65.00 & 60.00 \\
Maximum & 100.00 & 95.00 \\
Sum & $1,705.00$ & $1,370.00$ \\
Count & 19.00 & 19.00 \\
Confidence Level (95.0\%) & 5.36 & 5.75 \\
\hline
\end{tabular}

Pengujian data hasil pretest dan posttest diuji dengan menggunakan uji-t untuk mengetahui efektivitas model pembelajaran berbasis proyek terhadap hasil belajar mahasiswa dibanding dengan model pembelajaran konvensional. Hasil penghitungan F-Test Two-Sample for Variances (Tabel 2), diketahui $F$ hitung sebesar 0,87 dan $\mathrm{F}$ tabel sebesar 0,45, yang artinya terdapat pengaruh model pembelajaran berbasis proyek (Project Based Learning-PjBL) terhadap hasil belajar mahasiswa pada pembelajaran vulkanologi.

Tabel 2. F-Test Two-Sample for Variances

\begin{tabular}{lrr}
\hline & Eksperimen & Kontrol \\
\hline Mean & 89.74 & 72.11 \\
Variance & 123.54 & 142.54 \\
Observations & 19.00 & 19.00 \\
df & 18.00 & 18.00 \\
$\boldsymbol{F}$ & & $\mathbf{0 . 8 7}$ \\
$\boldsymbol{P}(\boldsymbol{F}<=$ f) one-tail & & $\mathbf{0 . 3 8}$ \\
$\boldsymbol{F}$ Critical one-tail & & $\mathbf{0 . 4 5}$ \\
\hline
\end{tabular}

Sedangkan hasil analisis menggunakan t-Test: Paired Two Sample for Means (tabel 3), menunjukkan bahwa efektivitas hasil belajar mahasiswa dengan menggunakan model pembelajaran berbasis proyek (Project Based Learning-PjBL) lebih baik dibanding model pembelajaran konvensional, dengan $\mathrm{t}$ hitung 3,80 lebih besar dari t tabel yaitu 2,10, dengan taraf nyata $\alpha=0,05$. 
Tabel 3. t-Test: Paired Two Sample for Means

\begin{tabular}{lrr}
\hline & Eksperimen & Kontrol \\
\hline Mean & 89.74 & 72.11 \\
Variance & 123.54 & 142.54 \\
Observations & 19.00 & 19.00 \\
Pearson Correlation & & $-\mathbf{0 . 5 4}$ \\
Hypothesized Mean Difference & & $\mathbf{0 . 0 0}$ \\
df & & $\mathbf{1 8 . 0 0}$ \\
$\boldsymbol{t}$ Stat & & $\mathbf{3 . 8 0}$ \\
$\boldsymbol{P}(\boldsymbol{T}<t)$ one-tail & & $\mathbf{0 . 0 0}$ \\
$\boldsymbol{t}$ Critical one-tail & & $\mathbf{1 . 7 3}$ \\
$\boldsymbol{P}(\boldsymbol{T}<=t)$ two-tail & & $\mathbf{0 . 0 0}$ \\
$\boldsymbol{t}$ Critical two-tail & & $\mathbf{2 . 1 0}$ \\
\hline
\end{tabular}

Berdasarkan hasil analisis dan uji statistik, dapat diketahui rata-rata hasil belajar mahasiswa pada kelas eksperimen lebih tinggi daripada kelas kontrol. Hal tersebut disebabkan dalam aktivitas belajar, kelas eksperimen mampu mengembangkan kemampuan berpikir tinggi dan kreativitas serta melatih kesiapan dalam menanggapi maupun menyelesaikan masalah. Berbeda halnya dengan model konvensional, yang sifatnya transfer pengetahuan tanpa mengembangkan kemampuan bekerjasama atau kelompok.

Berdasarkan gambar 2, dapat dilihat aktivitas mahasiswa dalam proses pembelajaran, dimana dalam kelas kontol para mahasiswa hanya mendengar ceramah dan diskusi searah dari dosen serta kurang interaksi antara mahasiswa dengan dosen sangat. Berbeda halnya, dengan kelas eksperimen yang menggunakan metode pembelajaran berbasis proyek hampir seluruh mahasiswa dalam kelas dapat mengambil bagian dalam proses pembelajaran berlangsung seperti ditunjukkan pada gambar 3. Hal tersebut sejalan dengan Buck Institute for Education dalam Wulandari (2016) yang menyatakan bahwa Pembelajaran berbasis proyek (Project Based Learning) merupakan metode belajar yang sistematis, yang melibatkan mahasiswa dalam belajar pengetahuan dan keterampilan melalui proses pencarian/penggalian (inkuiri) yang panjang dan terstruktur terhadap pertanyaan yang otentik dan kompleks serta tugas dan produk yang dirancang dengan sangat hati-hati. Pembelajaran berbasis proyek juga memiliki potensi untuk melatih meningkatkan aktivitas dan motivasi belajar siswa. (Kristanti, Subiki, \& Handayani, 2016)

Gambar 2. Kelas dengan menggunakan Model

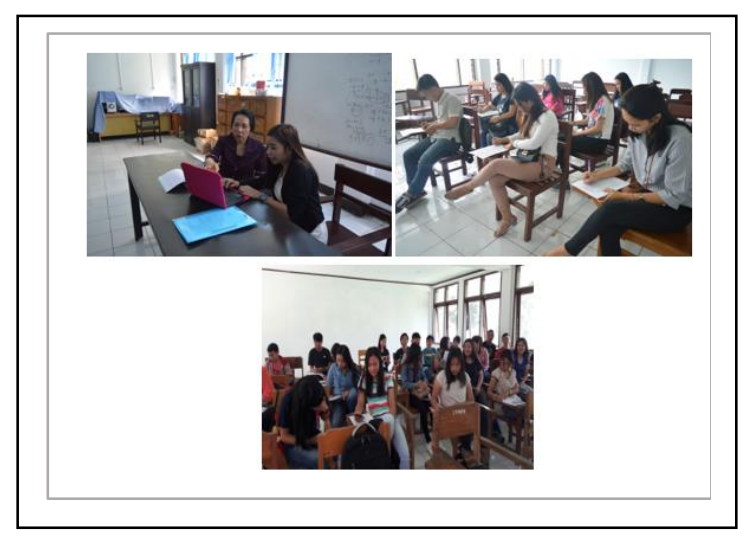

Pembelajaran Konvensional

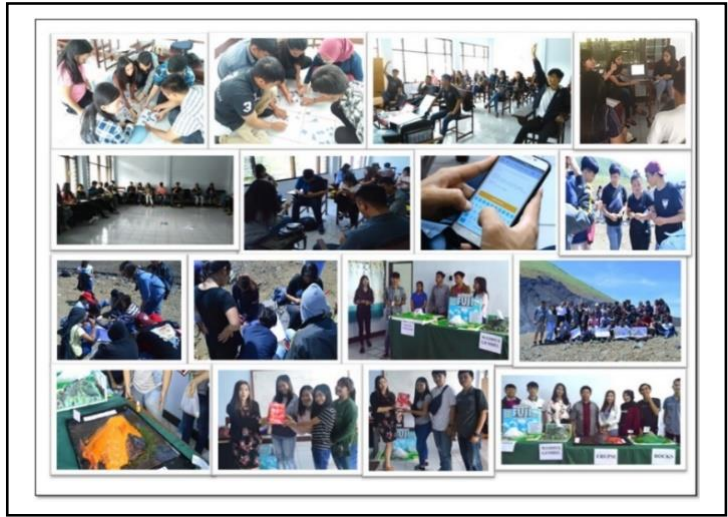

Gambar 3. Kelas dengan menggunakan Model Pembelajaran Berbasis Proyek - PjBL

Hasil penelitian menunjukan bahwa mahasiswa membutuhkan perbandingan dalam pendidikan dan pengajaran untuk memahami materi perkuliahan seperti konsep manifestasi sumber panas bumi yang ada di Sulawesi utara melalui pembelajaran mata kuliah Vulkanologi berbasis proyek. Pemahaman dari sebagian besar mahasiswa terhadap materi konsep manifestasi sumber panas bumi melalui pembelajaran mata kuliah vulkanologi berbasis proyek menunjukkan sikap memahami akan manifestasi vulkanologi lokal yang perlu di kembangkan.

\section{KESIMPULAN}

Rata-rata hasil pencapaian belajar mahasiswa pada kelas eksperimen dengan penerapan Model Project Based Learning yaitu $89,74 \%$, tergolong lebih tinggi 
dibandingkan belajar dengan penerapan Model Pembelajaran Konvensional yaitu 72.11\%. Sedangkan Hasil analisis t-Test diperoleh thitung 3,80 lebih besar dari t tabel yaitu 2,10 dengan taraf nyata $\alpha=0,05$, yang menunjukan bahwa efektivitas model pembelajaran berbasis proyek (Project Based Learning-PjBL) terhadap hasil belajar mahasiswa lebih baik dibanding model pembelajaran konvensional.

Disimpulkan, hasil tersebut terdapat pengaruh penggunaan Model Project Based Learning (PjBL) terhadap hasil belajar mahasiswa dalam pembelajaran mata kuliah vulkanologi. Hal ini dapat dilihat dari aktivitas kegiatan pembelajaran, yaitu sebagian besar mahasiswa menyatakan metode pembelajaran berbasis proyek, mendorong dan memiliki keinginan untuk berhasil, menginginkan penghargaan dalam belajar, melakukan kegiatan yang menarik dalam belajar dan memiliki lingkungan belajar yang kondusif serta harapan dan citacita untuk masa depan.

\section{SARAN}

Model Project Based Learning (PjBL) atau pembelajaran berbasis proyek dapat digunakan dalam pembelajaran untuk mengatasi kejenuhan mahasiswa pada suasana belajar di dalam kelas, sehingga mahasiswa dapat merasakan suasana yang berbeda dan dapat belajar langsung melalui lingkungan yang ada di sekitarnya.

Dosen yang hendak menerapkan model pembelajaran berbasis proyek diharapkan dapat merencanakan dengan matang sebelum pelaksanaan pembelajaran, seperti kondisi lingkungan, alokasi waktu, dan kegiatan yang akan dilaksanakan.

Pihak Fakultas atau Universitas dapat menyarankan kepada para dosen untuk menggunakan model atau metode pembelajaran inovatif seperti Project Based Learning $(\mathrm{PjBL})$ dalam pembelajaran atau perkuliahan.

\section{DAFTAR PUSTAKA}

Ida Ayu Kade, S., Sadia, W., \& Muderawan, I. W. (2013, Agustus). Pengaruh Model Pembelajaran Berbasis Proyek Terhadap Pemahaman Konsep Kimia dan Ketrampilan Berpikir Kritis. Jurnal Pendidikan IPA Indonesia, Corpus ID : 1427327333.

Kristanti, Y. D., Subiki, \& Handayani, R. D. (2016). Model Pembelajaran Berbasis Proyek (Project Based Learning Model) Pada Pembelajaran Fisika di SMA. Jurnal Pembelajaran Fisika, Vol. 5, No. 2 (122 - 128).

Londa, T. K., Warouw, F. F., \& Nusa, J. G. (2019). Environmental Learning With Inquiry Method in Tondano Lake. Advances in Social Science, Educaton and Humanities Research, Volume 438 4th Asian Education Symposium.

Mambu, M. C., Londa, T. K., \& Liando, N. V. (2018). Would Students Learn Better With Media? Advances in Social Science, Educaton and Humanities Research, Volume 253 3rd Asian Education Symposium.

Ngalimun. (2013). Perkembangan dan Pengembangan Kreativitas. Yogyakarta: Aswaja Pressindo.

Sudjana, N. (2010). Penilaian Hasil Prose Belajar Mengajar (Cet. XV). Bandung: PT. Remaja Rosdakarya.

Sugiyono. (2012). Metode Penelitian Kualitatif, Kuantatif, dan $R \& D$ (Cetakan-7). Bandung: Alfabeta.

Wulandari, F. E. (2016, Agustus). Pengaruh Pembelajaran Berbasis Proyek Untuk Melatihkan Keterampilan Proses Mahasiswa. JURNAL PEDAGOGIA, Volume. 5, No. 2 (247-254). 